\title{
Diagnostic Markers of Primary Infertility in Women of Reproductive Age with Hypothalamic Dysfunction in the Pubertal Period
}

\author{
Irina V. Zhukovets, $\mathrm{PhD}^{1,2 *}$; Olga Ya. Leshchenko, $\mathrm{PhD}, \mathrm{ScD}^{1}$; Alina V. Atalyan, $\mathrm{PhD}^{1}$ \\ IScientific Centre for Family Health and Human Reproduction Problems, Irkutsk, the Russian Federation \\ ${ }^{2}$ Amur State Medical Academy, Blagoveshchensk, the Russian Federation
}

\begin{abstract}
The aim of the study was to assess fertility in women of reproductive age with hypothalamic dysfunction (HD) in the pubertal period and to determine the diagnostic significance of pro-inflammatory (TNF- $\alpha$ and IL-1 $\beta$ ), anti-inflammatory cytokine (IL-10) and NF-kB activity in the diagnosis of primary infertility in these women.

Materials and Methods: Fertility was assessed in 86 women of reproductive age with HD in the pubertal period. A comparative characteristic of fertile women (Group 1, $\mathrm{n}=46$ ) and primary infertility women (Group 2, $\mathrm{n}=21$ ) with HD in the pubertal period was performed. FPG and FPI were determined after 8 to 12 hours of fasting. Serum IRI concentrations were measured using an ELISA kit. The levels of TNF- $\alpha$, IL-1 $\beta$ and IL-10 were determined in the venous blood serum after a 12-hour fasting, as well as in uterine aspirate (UA) on the 21 st day of the menstrual cycle using ELISA kits. The activity of NF-kB was determined in UA on the $21^{\text {st }}$ day of the menstrual cycle using an enzyme immunoassay kit.

Results: BMI in Group 1 was significantly lower than in Group 2: $22.63 \pm 2.68 \mathrm{~kg} / \mathrm{m}^{2}$ versus $27.05 \pm 4.03 \mathrm{~kg} / \mathrm{m}^{2}(P=0.000)$. WC in women of Group 1 was $66.11 \pm 5.66 \mathrm{~cm}$ versus $78.52 \pm 10.54 \mathrm{~cm}$ in Group $2(P=0.000)$; WC $>80 \mathrm{~cm}$ was found in $2(4.4 \%)$ and $14(66.7 \%)$ women, respectively $(P=0.000)$. The average levels of FPG and FPI were significantly higher in Group 2 . Serum levels of TNF- $\alpha$ and IL-1 $\beta$ in Group 2 were significantly higher than in Group 1 . The serum level of anti-inflammatory cytokine IL-10 was significantly lower in Group 2; accordingly, the TNF- $\alpha / \mathrm{IL}-10$ ratio in Group 2 was 1.8 times higher than in Group 1 . The IL-1 $\beta$ level in UA $(P=0.000)$ and the TNF- $\alpha / \mathrm{IL}-10$ ratio $(P=0.02)$ were significantly higher in women of Group 2 than Group 1 , which indicated the pronounced inflammatory effects of TNF- $\alpha$ in the endometrium. In women of Group 2, the NF-kB level in UA was 1.4 times higher than in Group $1(P=0.000)$.

Conclusion: Every fourth woman of reproductive age with HD in the puberty period has primary infertility. The results obtained indicate the activation of the Th-1 immune response with the formation of the inflammatory reactions at the systemic level and in the endometrium. Diagnostically significant markers of primary infertility are the serum TNF- $\alpha$ level and the UA levels of IL-1 $\beta$ and NF-kB. (International Journal of Biomedicine. 2017;7(3):213-217.)
\end{abstract}

Key Words: hypothalamic dysfunction $\bullet$ primary infertility $\bullet$ endometrium $\bullet$ cytokines

\section{Abbreviations}

BMI, body mass index; FPG, fasting plasma glucose; FPI, fasting plasma insulin; HD, hypothalamic dysfunction; IRI, immunoreactive insulin; IR, insulin resistance; UA, uterine aspirate (an aspirate from the uterine cavity); WC, waist circumference.

\section{Introduction}

In recent years, more attention has been paid to the development of reproductive health and the reproductive potential of adolescent girls, as future mothers. It has been

*Corresponding author: Irina V. Zhukovets, PhD. Head of Department of Obstetrics and Gynecology, Amur State Medical Academy. Blagoveshchensk, Russia.E-mail: zhukovec040875@mail.ru noted that in the Russian Federation in the 16-17 age group, the prevalence of endocrine pathology is 5 times higher than in the whole population..$^{(1)}$ According to the data of a number of researchers, the prevalence of HD in the pubertal period among girls is from $7.1 \%$ to $25 \%{ }^{(2,3)}$ On the background of $\mathrm{HD}$, obesity has been diagnosed in $61.1 \%$ of adolescent girls. ${ }^{(4)}$ Analysis of prospective studies shows that HD in the pubertal period leads to excess body weight in the reproductive age ${ }^{(5,6)}$ and increases the frequency of reproductive disorders by 2 
times. ${ }^{(3,7,8)}$ According to the data of a number of researchers, a slight inflammatory process is formed on the background of obesity. ${ }^{(7,9-11)}$ Pro-inflammatory cytokines secreted by fat tissue affect the state of the endometrium and ovulation. ${ }^{(11-13)}$ In this regard, studying a number of proinflammatory and anti-inflammatory cytokines at the systemic and local levels in women of reproductive age with HD in the pubertal period is the most promising way of determining the diagnostic markers of primary infertility.

The aim of the study was to assess fertility in women of reproductive age with $\mathrm{HD}$ in the pubertal period and to determine the diagnostic significance of pro-inflammatory (TNF- $\alpha$ and IL$1 \beta$ ), anti-inflammatory cytokine (IL-10) and NF-kB activity in the diagnosis of primary infertility in these women.

A prospective study was conducted between 2000 and 2013. The mean follow-up was $4.7 \pm 1.7$ years. Of the 170 potential participants in the pubertal period, 86 were enrolled in the study at the reproductive age, and 84 were excluded from the study.

The study protocol was reviewed and approved by the Ethics Committee of Amur State Medical Academy. All participants provided the written informed consent. Inclusion criteria were age over 18 years, HD (ICD-10-CM E23.3) manifested by the neuroendocrine (excessive body weight or obesity) and neurotrophic (pink or white striae) disorders according to electroencephalography (EEG) in the pubertal period. Exclusion criteria were tubal infertility (ICD-10-CM $\mathrm{N}$ 97.1), previous pelvic inflammatory diseases in history (ICD-10-CM N70 - N75), women of reproductive age who do not plan pregnancy.

In order to identify diagnostic markers of primary infertility in women of reproductive age, we performed a comparative characteristic of fertile women (Group 1, n=46) and primary infertility women (Group 2, n=21) with HD in the pubertal period. In the reproductive age, fertility categories were assessed in accordance with the standardized WHO protocol No.88093.

BMI is calculated using Quetelet's formula $\left(\mathrm{kg} / \mathrm{m}^{2}\right)$. The nature of the distribution of adipose tissue was determined by WC. WC $>0.80 \mathrm{~cm}$ showed an abdominal type of obesity according to IDF. FPG and FPI were determined after 8 to 12 hours of fasting. Serum IRI concentrations were measured using an ELISA kit (Monobind Inc., USA). To determine IR, Caro index was used (FPG(mmol/L)/IRI $(\mu \mathrm{IU} / \mathrm{ml}))$; Caro index $<0.33$ indicates IR.

Blood samples $(5 \mathrm{ml})$ for serological tests were obtained from the ulnar vein on an empty stomach at 8:00 a.m. Studies were carried out in paired sera. Samples of the sera were stored at $-20^{\circ} \mathrm{C}$. The levels of TNF- $\alpha$, IL- $1 \beta$ and IL-10 were determined in the venous blood serum after a 12-hour fasting, as well as in UA on the 21st day of the menstrual cycle using ELISA kits ("Interleukin 1-ELISA-BEST", "alpha"-TNFIFA-BEST (ZAO Vector-Best, Novosibirsk), Interleukin-10 (BenderMed Systems, USA)) according to the manufacturer's recommendations. The activity of NF-kB was determined in UA on the $21^{\text {st }}$ day of the menstrual cycle using an enzyme immunoassay kit (Cayman Chemical Co., USA) according to the manufacturer's recommendations.
Statistical analysis was performed using StatSoft Statistica v6.0. The mean (M) and standard deviation (SD) were calculated. Differences of continuous variables departing from the normal distribution, even after transformation, were tested by the Mann-Whitney $U$-test. Categorical variables were analyzed using the Chi-square test with the Yates' correction. Pearson's Correlation Coefficient (r) was used to determine the strength of the relationship between the two continuous variables. A probability value of $P<0.05$ was considered statistically significant.

\section{Results and Discussion}

Fertility was assessed in 86 women of reproductive age with HD in the pubertal period: $46(53.5 \%)$ women were found to be fertile, $21(24.4 \%)$ women were with primary infertility and $14(16.3 \%)$ with secondary infertility; 5(5.8\%) women were with unknown fertility and a male factor of infertility. According to the goal of the study, a comparative analysis was performed between the fertile women (Group 1, n=46)) and women with primary infertility (Group 2, $\mathrm{n}=21$ ).

The average age of women in the study groups did not differ significantly: $21.91 \pm 1.11$ years and $21.85 \pm 0.97$ years. BMI in Group 1 was significantly lower than in Group 2: $22.63 \pm 2.68 \mathrm{~kg} / \mathrm{m}^{2}$ versus $27.05 \pm 4.03 \mathrm{~kg} / \mathrm{m}^{2}(P=0.000)$. WC in women of Group 1 was $66.11 \pm 5.66 \mathrm{~cm}$ versus $78.52 \pm 10.54$ $\mathrm{cm}$ in Group $2(P=0.000)$; WC $>80 \mathrm{~cm}$ was found in $2(4.4 \%)$ and $14(66.7 \%)$ women, respectively $(P=0.000)$.

The average age at menarche for women in Group 1 and Group 2 was $11.67 \pm 0.76$ years and $11.52 \pm 0.92$ years, respectively, and did not differ significantly. Gynecological history in women of Groups 1 and 2 was complicated by oligomenorrhea (N91.3) in 2(4.35\%) and 9(42.9\%), respectively $(P=0.000)$, and by excessive and frequent menstruation (N92.0) in 2(4.35\%) and $8(38.1 \%)$, respectively $(P=0.001)$. Secondary amenorrhea (N91.1) in the reproductive age was diagnosed only in $1(2.2 \%)$ woman of Group 1. Abortion in the reproductive age with complications was found in $1(2.2 \%)$ woman of Group 1. There were no spontaneous abortions in women of both groups. Two $(4.3 \%)$ women of Group 1 had a delivery in their gynecologic history, and $11(23.9 \%)$ women of reproductive age in Group 1 used combined oral contraceptives to regulate the menstrual cycle and contraception.

The levels of FPG and FPI were determined in all women of Groups 1 and 2 (Table 1).

Analysis of carbohydrate metabolism showed that the average level of FPG was significantly higher in Group 2. The FPI level in women of Group 1 was 2.2 times lower than in Group 2. A Caro index $<0.33$ was found in $15(71.4 \%)$ women of Group 2 and in 6(13.3\%) women of Group $1(P=0.000)$.

To identify systemic immune disorders, serum levels of pro-inflammatory cytokines were determined. Serum levels of TNF- $\alpha$ and IL-1 $\beta$ in Group 2 were significantly higher than in Group 1 (Table 2). The serum level of anti-inflammatory cytokine IL-10 was significantly lower in Group 2; accordingly, the TNF- $\alpha /$ IL-10 ratio in Group 2 was 1.8 times higher than in Group 1. 
Table 1.

Parameters of carbohydrate metabolism in women with HD in the pubertal period

\begin{tabular}{|l|c|c|c|}
\hline \multicolumn{1}{|c|}{ Variable } & Group 1 $(\mathrm{n}=46)$ & Group 2 $(\mathrm{n}=21)$ & $P$ \\
\hline $\begin{array}{l}\text { FPG }, \mathrm{mmol} / 1 \\
(>6.1 \mathrm{mmol} / \mathrm{l})\end{array}$ & $4.27 \pm 0.51$ & $4.55 \pm 0.52$ & 0.03 \\
\hline $\begin{array}{l}\mathrm{FPI}, \mu \mathrm{IU} / \mathrm{ml} \\
(>20.0 \mu \mathrm{IU} / \mathrm{ml})\end{array}$ & $9.62 \pm 1.99$ & $20.97 \pm 10.75$ & 0.000 \\
\hline $\begin{array}{l}\text { Caro index } \\
(<0.33)\end{array}$ & $0.46 \pm 014$ & $0.28 \pm 0.16$ & 0.000 \\
\hline
\end{tabular}

Table 2.

Serum cytokine levels in women with HD in the pubertal period

\begin{tabular}{|l|c|c|c|}
\hline \multicolumn{1}{|c|}{ Variable } & Group 1 $(\mathrm{n}=34)$ & Group 2 $(\mathrm{n}=16)$ & $P$ \\
\hline TNF- $\alpha, \mathrm{pg} / \mathrm{ml}$ & $24.09 \pm 2.11$ & $28.63 \pm 3.85$ & 0.000 \\
\hline IL-1 $\beta, \mathrm{pg} / \mathrm{ml}$ & $39.77 \pm 3.27$ & $43.08 \pm 3.39$ & 0.001 \\
\hline IL-10, pg/ml & $13.56 \pm 1.05$ & $10.06 \pm 2.74$ & 0.000 \\
\hline TNF-a/IL-10 & $1.78 \pm 0.22$ & $3.17 \pm 1.35$ & 0.000 \\
\hline
\end{tabular}

We determined in UA the local immune disorders, the levels of the main Th-1 and Th- 2 cytokines involved in the regulation of the inflammatory process and NF-kB, as one of the regulators controlling the cascade of reactions associated with the cytokine activations. Thus, the serum level of TNF- $\alpha$ did not differ between the two groups, but the IL-1 $\beta$ level in UA was significantly higher in women of Group 2 than Group 1 ( $\mathrm{P}=0.000)$ (Table 3).

\section{Table 3.}

UA cytokine levels in women with HD in the pubertal period

\begin{tabular}{|l|c|c|c|}
\hline \multicolumn{1}{|c|}{ Variable } & Group 1 $(\mathrm{n}=34)$ & Group 2 $(\mathrm{n}=16)$ & $P$ \\
\hline TNF- $\alpha, \mathrm{pg} / \mathrm{ml}$ & $18.95 \pm 1.05$ & $19.73 \pm 3.91$ & 0.28 \\
\hline IL-1 $\beta, \mathrm{pg} / \mathrm{ml}$ & $28.24 \pm 1.41$ & $30.59 \pm 2.79$ & 0.000 \\
\hline IL-10, pg/ml & $5.87 \pm 1.88$ & $4.88 \pm 1.87$ & 0.08 \\
\hline TNF-a/IL-10 & $3.57 \pm 1.18$ & $4.59 \pm 1.88$ & 0.02 \\
\hline
\end{tabular}

The IL-10 levels in UA did not differ significantly between Groups 1 and 2, but the TNF- $\alpha / \mathrm{IL}-10$ ratio was 1.3 times higher in Group 2 than in Group 1 (3.57 \pm 1.18 and $4.59 \pm 1.88$, respectively, $P=0.02$ ), which indicated the pronounced inflammatory effects of TNF- $\alpha$ in the endometrium. Imbalance in the production of pro-inflammatory and antiinflammatory factors indicated the activation of the Th-1 immune response with the formation of the inflammatory reactions at the systemic level and in the endometrium, which is a factor in reducing its implantation ability. In women of Group 2, the NF-kB level in UA was 1.4 times higher than in Group 1: $8.76 \pm 1.74 \mathrm{pg} / \mathrm{ml}$ versus $6.33 \pm 1.0 \mathrm{pg} / \mathrm{ml}(P=0.000)$.

In Group 2, we found significant positive correlations between BMI and serum TNF- $\alpha$ level $(r=-0.63)$, BMI and IL-1 $\beta$ level in UA $(r=-0.60)$, BMI and NF-kB level in UA $(r=-0.81)$, as well as negative correlation between BMI and IL-10 level in UA $(r=-0.62)$ (Table 4).

Table 4.

Correlations between BMI and cytokine levels in the blood serum and $\boldsymbol{U A}$

\begin{tabular}{|l|c|c|c|c|}
\hline \multirow{2}{*}{\multicolumn{1}{c|}{ Variable }} & \multicolumn{2}{|c|}{ Group 1 $(\mathrm{n}=34)$} & \multicolumn{2}{c|}{ Group 2 $(\mathrm{n}=16)$} \\
\cline { 2 - 5 } & $r$ & $P$ & $r$ & $P$ \\
\hline TNF- $\alpha$ (serum) & -0.1 & 0.549 & 0.63 & 0.009 \\
\hline IL-1 $\beta$ (serum) & 0.18 & 0.273 & 0.40 & 0.115 \\
\hline IL-10 (serum) & 0.06 & 0.737 & -0.40 & 0.121 \\
\hline TNF- $\alpha$ (UA) & -0.14 & 0.393 & 0.18 & 0.494 \\
\hline IL-1 $\beta$ (UA) & 0.19 & 0.259 & 0.60 & 0.013 \\
\hline IL-10 (UA) & 0.14 & 0.393 & -0.62 & 0.009 \\
\hline NF-kB & 0.23 & 0.149 & 0.81 & 0.0001 \\
\hline
\end{tabular}

Thus, according to our data, an increase in BMI (1.2 times) and $\mathrm{WC}>80 \mathrm{~cm}(66.7 \%)$ against a background of an increase in PFF and insulin (2.2 times) indicated the formation of abdominal obesity in $66.7 \%$ of women and insulin resistance in $71.4 \%$ of women with primary infertility in the reproductive age with HD in the pubertal period.

As is well known, insulin stimulates the production of gonadotropic hormones in the hypothalamus, disrupting the cirroral rhythm, which affects the functioning of the hypothalamo-pituitary-ovarian axis..$^{(3,12,14)}$ The association between obesity and insulin resistance is largely due to changes in the function of adipose tissue. According to many authors, obesity plays a significant role in reproductive disorders, leading to fertility decline. ${ }^{(11,14)}$ Obesity may impair reproductive functions by affecting both the ovaries and endometrium. ${ }^{(15)}$ In several studies, it is found that the risk of infertility is threefold higher in obese women than in nonobese women ${ }^{(16)}$ and their fertility seems to be impaired in both natural and assisted conception cycles. ${ }^{(17,18)}$ It has been shown that the probability of pregnancy is reduced by $5 \%$ per unit of BMI exceeding $29 \mathrm{~kg} / \mathrm{m}^{2}$.(19) It has been unequivocally proven that fat is metabolically active; as a result of lipolysis, the release and production of a number of proinflammatory cytokines occur, ${ }^{(5,9)}$ which is also confirmed by our research. In primarily infertile women of reproductive age, such immune disorders as increasing the proinflammatory cytokines TNF- $\alpha$ and IL-1 $\beta$ and reducing the anti-inflammatory cytokine IL-10 with an increase in serum TNF- $\alpha /$ IL-10 ratio reflect the predominant Th1-type inflammatory response with the formation of systemic inflammatory reactions. Correlation analysis showed a direct relationship between BMI and serum TNF- $\alpha$ level. TNF $\alpha$ was the first cytokine to be implicated in the pathogenesis of obesity and insulin resistance. ${ }^{(2)}$ Adipose tissue expression of $\mathrm{TNF} \alpha$ is positively correlated with adiposity and insulin resistance. ${ }^{(20,-22)}$ Chronic exposure to $\mathrm{TNF} \alpha$ induces insulin resistance both in vitro and in vivo.$^{(22,23)}$ 
Many reports have shown that TNF- $\alpha$ may have an important role in the IR pathogenesis by multiple mechanisms, such as downregulation of genes that are required for normal insulin action, direct effects on insulin signaling, induction of elevated free fatty acids via stimulation of lipolysis, and negative regulation of peroxisome proliferator-activated receptor- $\gamma(\operatorname{PPAR} \gamma)$, an important insulin-sensitizing nuclear receptor. ${ }^{(24-27)}$ In addition, TNF- $\alpha$ functions as a modulator of gonadotropin release in the hypothalamus ${ }^{(28)}$ and an activator of intravascular coagulation. ${ }^{(10)}$ TNF- $\alpha$ is a pro-angiogenic factor and contributes to impaired vascularization of the endometrium. ${ }^{(28)}$

Investigation of the level of pro-inflammatory cytokines in UA showed the diagnostic significance of an increase in IL- $1 \beta$ level and the TNF- $\alpha /$ IL- 10 ratio in women with primary infertility. We found a direct correlation between BMI and IL-1 $\beta$ level and an inverse correlation between BMI and IL10 . Based on the results of other authors, IL-1 $\beta$ increases the production of prostaglandins, causing uterine contractions, which may be important in miscarriages. ${ }^{(13)}$ IL-10, which is involved in the process of hemopoiesis and angiogenesis, has a powerful anti-inflammatory and immunomodulatory effect and plays a major role in suppressing the excessive production of pro-inflammatory mediators. ${ }^{(29)}$ The decrease in IL-10 level and the predominance of pro-inflammatory cytokines over anti-inflammatory cytokines can alter the direction of the mother's immune response with the formation of the inflammatory reactions in the endometrium, which is a factor in reducing its implantation ability.

The correlation analysis also showed a direct, strong correlation between BMI and NF-kB in UA. NF-kB as a transcription factor is involved in the control of a large number of normal cellular and organismal processes, such as immune and inflammatory responses, developmental processes, cellular growth, and apoptosis. ${ }^{(30)}$ These capacities of NF$\mathrm{kB}$ can be used in the diagnosis of the implant ability of the endometrium.

In conclusion, every fourth woman of reproductive age with HD in the puberty period has primary infertility. The results obtained indicate the activation of the Th-1 immune response with the formation of the inflammatory reactions at the systemic level and in the endometrium. Diagnostically significant markers of primary infertility are the serum TNF- $\alpha$ level and the UA levels of IL-1 $\beta$ and NF-kB.

\section{Competing interests}

The authors declare that they have no competing interests.

\section{References}

1. Leshchenko OYa. Reproductive potential of modern man (analytical review). Pediatric and Adolescent Reproductive Health. 2013.(5):10-22. [Article in Russian].

2. Labygina AV, Kolesnikova LI, Suturina LV, Danusevich IN. [Hormonal metabolic and immunogenetic characteristics of women with hypothalamic syndrome, obesity and reproductive disorders]. Collection of scientific papers, Sworld. 2013;(2):70-78. [Article in Russian].
3. Uvarova EV, Khashchenko EP. [Hypothalamic dysfunction: etiopathogenesis and clinic (literature review)]. Pediatric and Adolescent Reproductive Health. 2010;(1):6576. [Article in Russian].

4. Zhukavets IV, Leshchenko OYa, Atalyan AV. [Somatic health and menstrual cycle in obese and overweight adolescent girls with hypothalamic dysfunction]. Pediatric and Adolescent Reproductive Health. 2016;(4):50-58. [Article in Russian].

5. Kovaleva YuV. [The role of obesity in the development of menstrual and reproductive disorders]. Ross Vest Akush Ginekol. 2014;(2):43-51. [Article in Russian].

6. Liu C, Elmquist JK. Tipping the scales early: probing the long-term effects of obesity. J Clin Invest. 2012;122(11):38402. doi: $10.1172 /$ JCI66409

7. Kolesnikova LI, Kolesnikov SI, Darenskaya MA, Grebenkina LA, Nikitina OA, Lazareva LM, et al. Activity of LPO Processes in Women with Polycystic Ovarian Syndrome and Infertility. Bull Exp Biol Med. 2017;162(3):320-322. doi: 10.1007/s10517-017-3605-5.

8. West S, Lashen H, BloiguA, Franks S, Puukka K, Ruokonen A, et al. Irregular menstruation and hyperandrogenaemia in adolescence are associated with polycystic ovary syndrome and infertility in later life: Northern Finland Birth Cohort 1986 study. Hum Reprod. 2014;29(10):2339-51. doi: 10.1093/ humrep/deu200.

9. Salikhova AF, Farkhutdinova LM. [Immunological features of obesity and their interrelation with violations of a carbohydrate and fatty exchanges]. Med Immunologiia. 2013;15(5):465-470. [Article in Russian].

10. Stilidi EI. [The role of tumor necrosis factor alpha and interleukin-6 in the pathogenesis of NASH]. Krimskii Ter Zhurnal. 2012;18(1):91-98.[Article in Russian].

11. Bohler HJ, Mokshagundam S, Winters SJ. Adipose tissue and reproduction in women. Fertil Steril. 2010;94(3):795-825. doi: 10.1016/j.fertnstert.2009.03.079.

12. Shpakov AO. [Functional state of the hypothalamicpituitary-gonadal axis in diabetes mellitus]. Problemi Endocrinologii. 2010;56(5):23-29.[Article in Russian].

13. Zastavna D, Sosnina K, Terpylyak O, Huleyuk N, Bezkorovayna H, Mikula M, Helner N. Cytogenetic and immunogenetic analysis of recurrent pregnancy loss in women. Tsitol Genet. 2014;48(4):44-50.

14. Pasquali R. The hypothalamic-pituitary-adrenal axis and sex hormones in chronic stress and obesity: pathophysiological and clinical aspects. Ann N Y Acad Sci. 2012;1264:20-35. doi: 10.1111/j.1749-6632.2012.06569.x.

15. Bellver J, Melo MA, Bosch E, Serra V, Remohi J, Pellicer A. Obesity and poor reproductive outcome: the potential role of the endometrium. Fertil Steril. 2007;88:446-51 .

16. Rich-Edwards JW, Goldman MB, Willet WC, Hunter DJ, Stamfer MJ, Colditz GA, et al. Adolescent body mass index and infertility caused by ovulation disorders. Am J Obstet Gynecol. 1994;171(1):171-7.

17. Zaadstra BM, Seidell JC, Van Noord PA, te Velde ER, Habbema JA, Vrieswijk B, Karbaat J. Fat and female fecundity: prospective study of effect of body fat distribution on conception rates. BMJ. 1993;306(6876):484-7.

18. Crosignani PG, Ragni G, Parazzini F, Wyssling $\mathrm{H}$, Lombrosso G, Perotti L. Anthropometric indicators and response to gonadotrophin for ovulation induction. Hum Reprod. 1994;9(3):420-3.

19. Van der Steeg JW, Steures P, Eijkemans MJ, Habbema JD, Hompes PG, Burggraaff JM, et al. Obesity affects spontaneous 
pregnancy chances in subfertile ovulatory women. Hum Reprod. 2008;23(2):324-8

20. Hotamisligil GS1, Shargill NS, Spiegelman BM. Adipose expression of tumor necrosis factor-alpha: direct role in obesitylinked insulin resistance. Science. 1993;259(5091):87-91.

21. Hotamisligil GS. Inflammatory pathways and insulin action. Int J Obes Relat Metab Disord. 2003;27 Suppl 3:S53-5. 22. Ruan H1, Lodish HF.Insulin resistance in adipose tissue: direct and indirect effects of tumor necrosis factor-alpha. Cytokine Growth Factor Rev. 2003;14(5):447-55.

23. Ryden M, Dicker A, van Harmelen V, Hauner $H$, Brunnberg M, Perbeck L, et al. Mapping of early signaling events in tumor necrosis factor-alpha -mediated lipolysis in human fat cells. J Biol Chem. 2002;277(2):1085-91.

24. Costa NT, Veiga Iriyoda TM, Kallaur AP, Delongui F, Alfieri DF, Lozovoy MA, et al. Influence of Insulin Resistance and TNF- $\alpha$ on the Inflammatory Process, Oxidative Stress, and Disease Activity in Patients with Rheumatoid Arthritis. Oxid Med Cell Longev. 2016;2016:8962763. doi: 10.1155/2016/8962763.

25. Zou C, Shao J. Role of adipocytokines in obesity-associated insulin resistance. J Nutr Biochem. 2008;19(5):277-86.
26. Aguirre V, Uchida T, Yenush L, Davis R, White MF. The c-Jun NH2-terminal kinase promotes insulin resistance during association with insulin receptor substrate-1 and phsosphorylation of Ser(307). J Biol Chem. 2000;275(12):9047-54.

27. Groop LC, Saloranta C, Shank M, Bonadonna RC, Ferrannini E, DeFronzo RA. The role of free fatty acid metabolism in the pathogenesis of insulin resistance in obesity and noninsulin- dependent diabetes mellitus. J Clin Endocrinol Metab. 1991;72(1):96-107.

28. Shevyakov SA, Zakharov IuM. [Studying of the role of tumor necrosis factor-alpha in regulation of erythropoiesis in erythroblastic islands cultures]. Ross Fiziol Zh Im I M Sechenova. 2013;99(8):993-1001. [Article in Russian]

29. Pavlov OV, Sel'kov SA. [In vitro production of IL-10 and IL-11 as a manifestation of «alternative activation» of placental macrophages]. Immunologiia. 2011;32(6):301-306 [Article in Russian].

30. Kaidashev IP. [Conception for permanent activation of nuclear factor $\mathrm{kB}$ as molecular basis for metabolic syndrom pathogenesis]. Patol Fiziol Eksp Ter. 2013;(3):65-72. [Article in Russian]. 